\title{
Growing-Season Disturbance in Tallgrass Prairie: Evaluating Fire and Grazing on Schizachyrium scoparium
}

\author{
Ryan F. Limb, ${ }^{1}$ Samuel D. Fublendorf, ${ }^{2}$ David M. Engle, ${ }^{2}$ and Jay D. Kerby ${ }^{3}$ \\ Authors are ${ }^{1}$ Senior Research Specialist, ${ }^{2}$ Professor, and ${ }^{3}$ Research Associate, Department of Natural Resource Ecology and Management, \\ Oklahoma State University, Stillwater, OK 74075, USA.
}

\begin{abstract}
Historically, fire occurred throughout the year in the Great Plains, but current fire prescriptions are generally limited to the dormant season because of concerns for potential damage to fire-sensitive herbaceous plant species deemed economically and ecologically important. We coupled a field-based study and a controlled greenhouse study to quantify the effects of fire season and herbivory on plant species composition, along with survival and productivity of little bluestem (Schizachyrium scoparium [Michx.] Nash). We investigated the effects of both dormant and growing-season fire interacting spatially with grazing on plant community composition in a 10-yr field study. We also examined the influence of both growing-season fire and clipping on survival and aboveground and belowground production of potted little bluestem plants at multiple ages in a controlled greenhouse experiment. Plants were grown to $6 \mathrm{wk}, 10 \mathrm{wk}$, or $18 \mathrm{wk}$, then either burned or clipped, followed by as many as two successive clipping events. Plant community composition and canopy cover of little bluestem were unaffected by season-ofburning in the field study. Survival of individual little bluestem seedlings in the greenhouse study was dependent primarily on plant age, with nearly $100 \%$ survival among all burning and clipping treatments at $18 \mathrm{wk}$ old. Burning or clipping once did not decrease survival compared to seedlings that were not burned or not clipped, and burning followed by clipping did not decrease survival over multiple clipping events among 6-wk-, 10-wk-, or 18-wk-old plants. Both aboveground regrowth and belowground biomass increased with burning, but clipping reduced regrowth. Based on both field and greenhouse experiments, we conclude that little bluestem is well adapted to growing-season disturbance. Moreover, little bluestem responds more positively to growing-season fire than to clipping. Our results provide no evidence that little bluestem should be deferred from grazing after burning as part of a rangeland management strategy.
\end{abstract}

\section{Resumen}

Históricamente, los fuegos en las Grandes Planicies de América del Norte ocurrían a lo largo del año, pero en la actualidad las quemas prescriptas están generalmente limitadas a la estación de quiescencia para evitar potenciales daños a plantas herbáceas sensibles al fuego, consideradas de importancia ecológica y económica. Asociamos un ensayo de campo y un experimento controlado de invernáculo para cuantificar los efectos de la estación del fuego y la herbivoría sobre la composición de especies vegetales junto con la supervivencia y productividad de Schizachyrium scoparium [Michx.] Nash. Investigamos los efectos de quemas durante los períodos de quiescencia y de crecimiento y su interacción espacial con el pastoreo sobre la composición de la comunidad vegetal en un ensayo de campo de 10 años. También investigamos los efectos del fuego durante la estación de crecimiento y la defoliación sobre la sobrevivencia y la producción aérea y subterránea de plantas de $S$. scoparium cultivadas en macetas hasta edades múltiples en un experimento controlado de invernáculo. Las plantas fueron quemadas o defoliadas a las 6, 10 o 18 semanas y luego fueron sometidas a dos eventos sucesivos de defoliación. La composición de la comunidad vegetal y la cobertura de canopeo de $S$. scoparium no fueron afectadas por la estación de quema en el ensayo de campo. La sobrevivencia de plántulas de S. scoparium en el invernáculo dependió principalmente de la edad de la planta, con aproximadamente el 100\% de sobrevivencia en todos los tratamientos de fuego y defoliación a las 18 semanas de edad. La aplicación de un solo evento de fuego y defoliación no disminuyó la sobrevivencia comparado con plántulas que no fueron quemadas ni defoliadas, y la quema seguida de defoliación no disminuyó la sobrevivencia a lo largo de múltiples eventos de defoliación en plantas de 6, 10, o 18 semanas de edad. Tanto el rebrote aéreo como la biomasa subterránea aumentaron con el fuego, pero la defoliación redujo el rebrote. Basados en nuestros ensayos de campo e invernáculo, concluimos que $S$. scoparium demuestra buena adaptación a disturbios aplicados durante la estación de crecimiento. Además, S. scoparium responde mejor al fuego aplicado durante la estación de crecimiento que a la defoliación. Nuestros resultados no proveen evidencia que indique que se deba diferir el pastoreo $S$. scoparium luego de una quema como parte de una estrategia de manejo de pastizales naturales.

Key Words: burning, defoliation, mortality, productivity, pyric herbivory, regrowth, root growth

\footnotetext{
This research was funded by the Oklahoma Agricultural Experiment Station and the Nationa Research Initiative of the US Department of Agriculture Cooperative State Research, Education and Extension Service, grant numbers 2003-35101-12928 and 2006-35320-17476. Correspondence: Ryan F. Limb, 008c Agricultural Hall, Stillwater, OK 74078, USA. Email: ryan.limb@okstate.edu

Manuscript received 25 January 2010; manuscript accepted 3 October 2010.
}

\section{INTRODUCTION}

Natural disturbance is an inevitable and influential factor within terrestrial biomes throughout the world. The effects of disturbance on species assemblages can be complex, depending on the type, extent, severity, frequency, and seasonal timing of each disturbance (Sousa 1984; Limb et al. 2010a). Land 
management, in a broad and general context, is the application and manipulation of planned disturbances to achieve desired outcomes. Often, successful land management strategies incorporate or mimic historic disturbances for which the plant communities are adapted (Whisenant 1999). Often there is considerable uncertainty of the effects of disturbance timing, frequency, and intensity on individual species or communities.

Many grasslands evolved with frequent defoliation, so plants developed attributes enabling them to persist and even thrive with such disturbances (Axelrod 1985; Augustine and McNaughton 1998; Fuhlendorf and Engle 2001; Fuhlendorf and Engle 2004; Towne et al. 2005). Growing points at or near the soil surface reduce the likelihood of mortality and promote rapid regrowth following defoliation of dominant forage grasses (Palo and Robbins 1991). Defoliation during dormancy is least influential on plant survival, and can increase plant productivity and reproduction by increasing resource availability (Knapp et al. 1999). However, growing-season herbivory is widely accepted as a management tool for maintaining grassland diversity and stability as well as sustaining livestock and wildlife production (West 1993; Biondini et al. 1998; Collins et al. 1998; Limb et al. 2010a, 2010b). Research has shown that negative effects from growing-season grazing can be offset by reduced light limitation and subsequent increased vegetative reproduction, increased species richness, and sustained plant productivity and forage quality throughout a greater portion of the growing season (McNaughton 1984; Frank and McNaughton 1993; Peco et al. 2006). However, few studies have addressed whether similar indirect offsets occur following growing-season fires.

Fire is common through much of the Great Plains region as a natural disturbance and a land management tool (Vogl 1974). Fire reduces woody species cover, slows woody encroachment, and maintains herbaceous species dominance (Bragg and Hulbert 1976; Brown and Archer 1989; Fuhlendorf and Smeins 1997). Prior to European settlement, fires ignited by lightning and Native Americans could occur throughout the year during dormant and active growing seasons (Bragg 1982; Higgins 1986). Plant adaptations to fire and herbivory are similar traits (Rosenthal and Kotanen 1994), and both disturbances can benefit plant productivity and community composition by reducing light limitations and increasing the rate of nutrient turnover (Blair 1997; Johnson and Matchett 2001; Anderson et al. 2006). Prescribed fire in tallgrass prairie predominantly occurs during the dormant season (Wright and Bailey 1982; Engle and Bidwell 2001). However, there is increased use of growing-season fire to suppress woody species in much of the southern and central Great Plains (Twidwell et al. 2009). Growing-season fire reduces C4 grass production (Ewing and Engle 1988; Engle et al. 1993; Engle et al. 1998; Ansley et al. 2008), reduces plant canopy cover (Ford and Johnson 2006), and alters overall perennial plant community composition (Howe 1994). These negative effects form the basis for questioning the use of growing-season fire to sustain perennial herbaceous vegetation in grasslands and savannas (Taylor 2005), particularly when followed by livestock grazing (Britton 2005).

Pyric herbivory, the spatial and temporal coupling of fire and grazing, created a shifting pattern of disturbance across much of the Great Plains landscape before European settlement
(Fuhlendorf and Engle 2001; Fuhlendorf et al. 2009). Although the complex interactive effects of fire and herbivory have been investigated (Biondini et al. 1999; Fuhlendorf and Engle 2004; Archibald et al. 2005; Ansley et al. 2006), growing-season fire followed by grazing might damage physiologically active grasses, particularly immature plants or species that are thought to be disturbance sensitive.

Little bluestem (Schizachyrium scoparium [Michx.] Nash), a perennial C4 bunchgrass, is considered tolerant of growingseason herbivory. However, elevated growth points, and the tendency to accumulate biomass near the base of the plant, suggests (Butler and Briske 1988; Derner and Briske 1999) that it may be sensitive to growing-season fire (Bransen 1953; Wright and Bailey 1982). Previous studies report considerable negative effects (Anderson et al. 1970; Towne and Owensby 1984; Ewing and Engle 1988), neutral effects (Bidwell et al. 1990; Engle et al. 1990) and positive effects (Anderson et al. 1970) of growing-season fire on plant community cover and production. If growing-season fires have a negative effect on herbaceous vegetation, it may be due to either plant phenology at the time of the fire, or increased fire intensity resulting from increased ambient temperatures. We focus on plant age and burned actively growing plants that ranged from seedling to nearly mature. Previous studies concentrated on populationlevel rather than individual plant response to growing-season fire. From the studies that report neutral and positive responses, the causal mechanism at the individual-plant level is unclear. In this study we coupled a field-based study investigating effects of fire season on plant community dynamics and a controlled greenhouse study to examine the effects of growing-season fire, grazing, and plant age. Specifically we investigated the effects of 1) the spatio-temporal interaction of grazing with dormantseason fire and growing-season fire on little bluestem abundance, and 2) growing-season fire and clipping on plant survival and aboveground and belowground production of different aged individual little bluestem plants.

\section{METHODS}

Our field study was conducted at the Oklahoma State University Range Research Station (lat $36^{\circ} 06^{\prime} \mathrm{N}$; long $\left.97^{\circ} 23^{\prime} \mathrm{W}\right)$ located in central Oklahoma approximately $21 \mathrm{~km}$ southwest of Stillwater, Oklahoma. Mean annual precipitation is $846 \mathrm{~mm}$, of which $65 \%$ is received during the May-October growing season. The research station is situated within the North American tallgrass prairie ecoregion, where herbaceous vegetation is dominated by C4 grasses, including little bluestem, big bluestem (Andropogon gerardii Vitman), Indiangrass (Sorghastrum nutans [L.] Nash), switchgrass (Panicum virgatum L.), and tall dropseed (Sporobolus asper [Michx.] Kunth).

\section{Experimental Design}

Field Experiment-Dormant-Season Fire vs. Growing-Season Fire. To test the effects of the fire-grazing interaction on vegetation dynamics, a completely randomized design experiment was established in 1999 (Fuhlendorf and Engle 2004). Within three individual pastures $(0.8 \times 0.8 \mathrm{~km})$ six distinct 
patches were delineated and assigned either a dormant-season fire or growing-season fire treatment. Patches were burned on a 3 -yr cycle such that one-sixth of the pasture was burned in March for dormant-season treatments and July or August for growing-season treatments annually (Fig. 1). Grazing animals had equal access to both dormant-season and growing-season patches within each pasture, and selectively grazed recently burned patches, but did not show preference between the two burn seasons (Allred 2008); therefore differences that exist between the two patches can be attributed to fire season and not grazing. Weather conditions for both dormant- and growing-season fires varied over the duration of the study. Conditions for spring fires were generally $15-25^{\circ} \mathrm{C}$ with wind speed of $8-32 \mathrm{k} \cdot \mathrm{h}^{-1}$, and $32-45^{\circ} \mathrm{C}$ with wind speed of $8-$ $32 \mathrm{k} \cdot \mathrm{h}^{-1}$ for summer fires. Pastures were moderately stocked with mixed-breed cattle at $0.83 \mathrm{ha} \cdot$ animal unit month $^{-1}$ from 1999 through 2005. Starting in 2006, pastures were stocked with cow/calf pairs at the same stocking rate. Pastures did not contain internal fences, so cattle were allowed to graze selectively among the six patches. Canopy cover of plant functional groups was estimated in all patches annually prior to the summer burn treatment. Random subsampling with 30 0.1$\mathrm{m}^{2}$ quadrats per patch was used to monitor functional groups, including tallgrasses, little bluestem, other perennial grasses, annual grasses, forbs, the invasive legume sericea lespedeza (Lespedeza cuneata [Dum. Cours.] G. Don), and other legumes.

Greenhouse Experiment-Growing-Season Fire vs. Clipping. Little bluestem survival and production following disturbance by growing-season fire or simulated grazing (clipping) was determined by a greenhouse experiment following individual plants through time. Little bluestem (Aldous variety) seedlings were germinated and individually transplanted 2 wk after germination to $3.78-\mathrm{L}$ polystyrene containers containing sieved native clay loam soil from the Oklahoma State University Range Research Station. Plants received only ambient light through the greenhouse $(\bar{x}=13.35$ daylight hours) with day and night temperatures of $27^{\circ} \mathrm{C}$ and $21^{\circ} \mathrm{C}$, respectively. Pots were watered daily to maintain the soil in the pots at near water-holding capacity. At $7 \mathrm{wk}$ and $13 \mathrm{wk}$, all plants received an equal amount of nutrient solution of macronutrients $(\mathrm{N}, \mathrm{P}$, $\mathrm{K}$ ) and micronutrients (B, Cu, Mn, Fe, Mo, and $\mathrm{Zn}$ ) to augment the nutrient-poor soil.

Treatments were designed to compare plants that were either burned or not burned as well as plants that were burned and then clipped once or twice and plants that were not burned or clipped and plants that were not burned but were clipped one, two, or three times. Plants were clipped to $1-\mathrm{cm}$ height at $8-\mathrm{d}$ intervals (Table 1). That is, clipped plants were clipped on Day 1, some were clipped a second time on Day 9, and others were clipped a third time on Day 17, with termination of the study on Day 25. Plants that were burned (Day 1) were clipped $8 \mathrm{~d}$ after burning (Day 9); some were clipped a second time on Day 17, with the termination of the study on Day 25. If plants were not taller than $1 \mathrm{~cm}$, they were not clipped, so that residual heights were consistent. This resulted in $100 \%$ of plants clipped at Days 9 and 17 for burn treatments, and $28 \%$ and $42 \%$ were clipped for the same time period for clip-only plants. Burning and clipping treatments were designed to mimic herbivory and pyric herbivory (Fuhlendorf and Engle 2001, 2004; Fuhlendorf

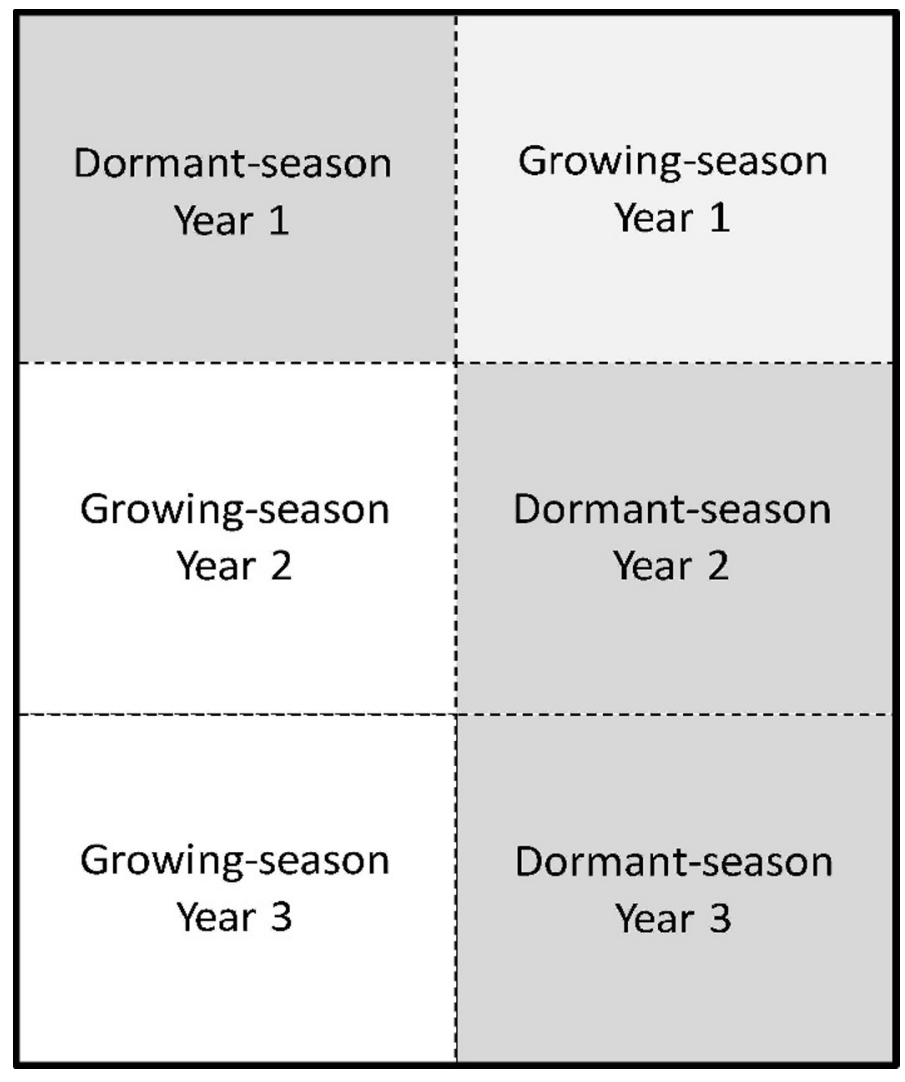

Figure 1. Spatial layout and arrangement of seasonal fires in a patch treatment pasture. The solid line represents a fence that encloses the pasture, whereas the dotted lines separate the burned patches, which are unfenced. Free movement of animals was allowed within each pasture.

et al. 2009). Therefore, treatments balanced the number of defoliation events, whether by fire or clipping or a combination of the two, rather than a factorial arrangement of burning and clipping treatments. For example, we purposely designed the experiment to compare the treatment that included burning followed by one clipping with the treatment that included no burning and two clipping events. The level of clipping $(1-\mathrm{cm}$ height) is admittedly severe; however, field observations indicate that this is the height of herbaceous vegetation in burned and grazed patches as well as grazing lawns that develop in unburned locations. These treatments were imposed on plants at $6 \mathrm{wk}, 10 \mathrm{wk}$, or $18 \mathrm{wk}$ postgermination to determine the effects of clipping and fire as a function of plant maturity. To account for temperature and light differences within the greenhouse, treatments to potted plants were arranged into three blocks (a bench being a block) with a group of four pots (subsamples) per treatment per block for a total of 12 observations (pots) per treatment. Burning was conducted on a $0.9 \times 1.8 \mathrm{~m}$ metal table with a $20-\mathrm{cm}$ circle removed from the center. Potted plants were placed in the center circle with the table raised to the height of the pot. To fuel the fire, $400 \mathrm{~g}$ of air-dry native herbaceous vegetation was placed uniformly on the table and at the base of the plant, leaving a $10-\mathrm{cm}$ margin from the table edge to ensure burning fuel stayed on the table, simulating approximately $3500 \mathrm{~kg}$. $\mathrm{ha}^{-1}$ fuel loads common among the field experiment. All burns were conducted with the use of a head fire with a constant 
Table 1. Defoliation (burn and/or clip) treatments applied to little bluestem plants in pots. Each set of treatments was applied to three replicates of potted little bluestem at $6 \mathrm{wk}, 10 \mathrm{wk}$, or $18 \mathrm{wk}$ postgermination.

\begin{tabular}{ccccc}
\hline & \multicolumn{4}{c}{ Sequence of defoliation treatments } \\
\cline { 2 - 5 } Clipping events & Day 1 & Day 9 & Day 17 & Day 25 \\
\hline 0 & Burned & & & \\
1 & Burned & Clipped & & \\
2 & Burned & Clipped & Clipped & \\
0 & & & & Harvest residual \\
1 & Clipped & & & \\
2 & Clipped & Clipped & & \\
3 & Clipped & Clipped & Clipped & \\
\hline
\end{tabular}

$7 \mathrm{k} \cdot \mathrm{h}^{-1}$ wind speed, $29-35^{\circ} \mathrm{C}$ air temperature, and $40-60 \%$ relative humidity. A thermocouple placed $1 \mathrm{~cm}$ above the soil surface recorded a mean fire temperature of $634^{\circ} \mathrm{C}(26 \mathrm{SE})$, which is similar to growing-season fire temperatures in a grassland ecosystem (Ansley et al. 2008).

Plant survival, aboveground regrowth biomass, and belowground biomass were averaged within each group of four pots of a treatment group at $24 \mathrm{~d}$ after the first clipping or burning treatment (Day 25). Aboveground biomass accumulated from germination to the date of first clipping event $(\bar{x}=22.9 \mathrm{~g})$ was assumed to be the same for the control and clip-only groups (18 wk postgermination). This was subtracted from the biomass harvested on Day 25 to estimate the aboveground biomass produced in the control treatment between Day 1 and Day 25, which corresponds with the regrowth produced in the treatment groups. Aboveground regrowth and belowground biomass were oven dried to a consistent weight.

\section{Data Analysis}

Field Experiment-Dormant-Season Fire vs. Growing-Season Fire. The mean relative canopy cover of each plant functional group was calculated within each pasture among the three dormant-season and three growing-season patches, with the patch as the experimental unit in this study. Relative little bluestem canopy cover was compared between dormant-season fire and growing-season fire patches for each year with the use of the repeated-measures $t$-test procedure in SPSS (SPSS 2005). We used permutation-based nonparametric multivariate analysis of variance analysis with a Sorensen distance measure (Anderson 2001) to compare the overall plant functional group composition between the dormant-season and growing-season fire treatments for all years of the study. We used a random integer starting point with 4999 iterations with the use of PCORD 5 software (McCune and Grace 2002).

Greenhouse Experiment-Growing-Season Fire vs. Simulated Grazing. Little bluestem plant survival, aboveground regrowth biomass (hereafter referred to as regrowth), and belowground biomass of treatments were analyzed with the use of ANOVA procedures in SPSS (SPSS 2005). Main effects (plant age, burning, and clipping) and their interactions were analyzed with analysis of variance. In the presence of a significant main effect and interactions, individual treatments (i.e., treatments

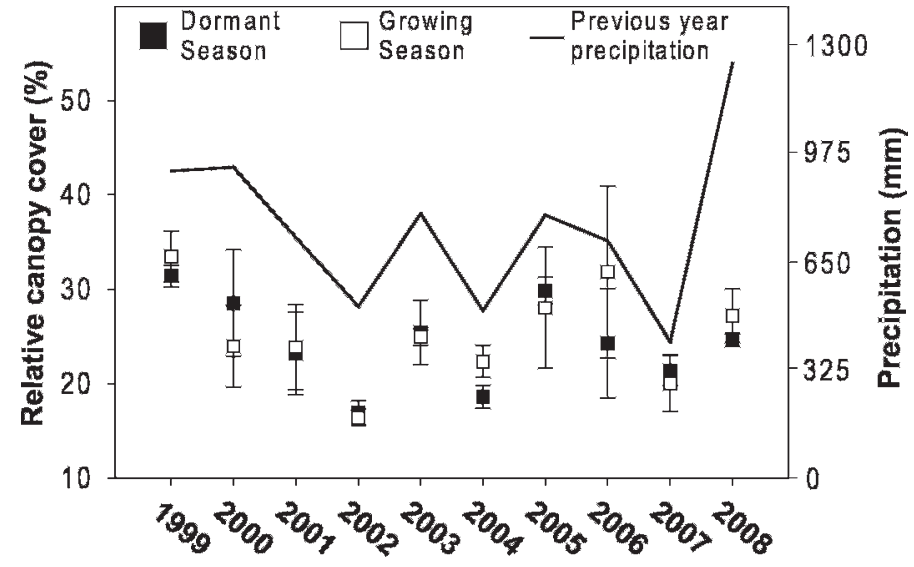

Figure 2. Mean $\pm \mathrm{SE}\left(Y_{1}\right)$ of relative little bluestem canopy cover within tallgrass prairie at the Oklahoma State University Research Range burned in the dormant season or growing season $(n=3)$. Annual precipitation $\left(Y_{2}\right)$ from 1999 to 2008 at the Oklahoma State University Range Research Station.

within an age class, a treatment across age classes) were compared with the Tukey mean separation procedure. Plant survival data were subjected to the arcsin transformation before analysis (Steel et al. 1997). Accumulated aboveground regrowth biomass and belowground biomass are reported only for 18-wk-old plants because of high mortality in the 6- and 10wk-old plants.

\section{RESULTS}

\section{Dormant-Season Fire vs. Growing-Season Fire}

The plant community averaged about $18 \%$ tall grasses, $25 \%$ little bluestem, $31 \%$ other perennial grasses, $1 \%$ annual grasses, $18 \%$ forbs, $5 \%$ sericea lespedeza, and $2 \%$ other legumes over the duration of the 10-yr study. Throughout the study, plant community composition did not differ $(P>0.05)$ between dormant-season and growing-season fire treatments (data not presented), and canopy cover of little bluestem did not differ $(P>0.05)$ between dormant-season fire and growingseason fire (Fig. 2). Variation in canopy cover between seasonof-fire treatments ranged nearly $2.5 \%$, and the range of canopy cover across years was more than $15 \%$ and generally mirrored annual variation in precipitation (Fig. 2).

\section{Growing-Season Fire vs. Simulated Grazing}

Little bluestem survival was influenced by the three-way interaction of plant age, burning, and clipping $(P \leq 0.05)$. Survival of little bluestem was influenced most by plant age (Fig. 3). Plant survival in 6-wk and 10-wk postgermination treatment groups was reduced by multiple defoliation events $(P \leq 0.05)$, but neither clipping nor burning alone or in combination reduced survival in the 18 -wk treatment group.

Burning alone and clipping once had similar effects on survival of little bluestem plants. Further, burning followed by a single clip or two clips did not decrease survival more than two clips or three clips alone, respectively, at all ages $(P>0.05)$ (Fig. 3). Survival of plants increased in all disturbance 

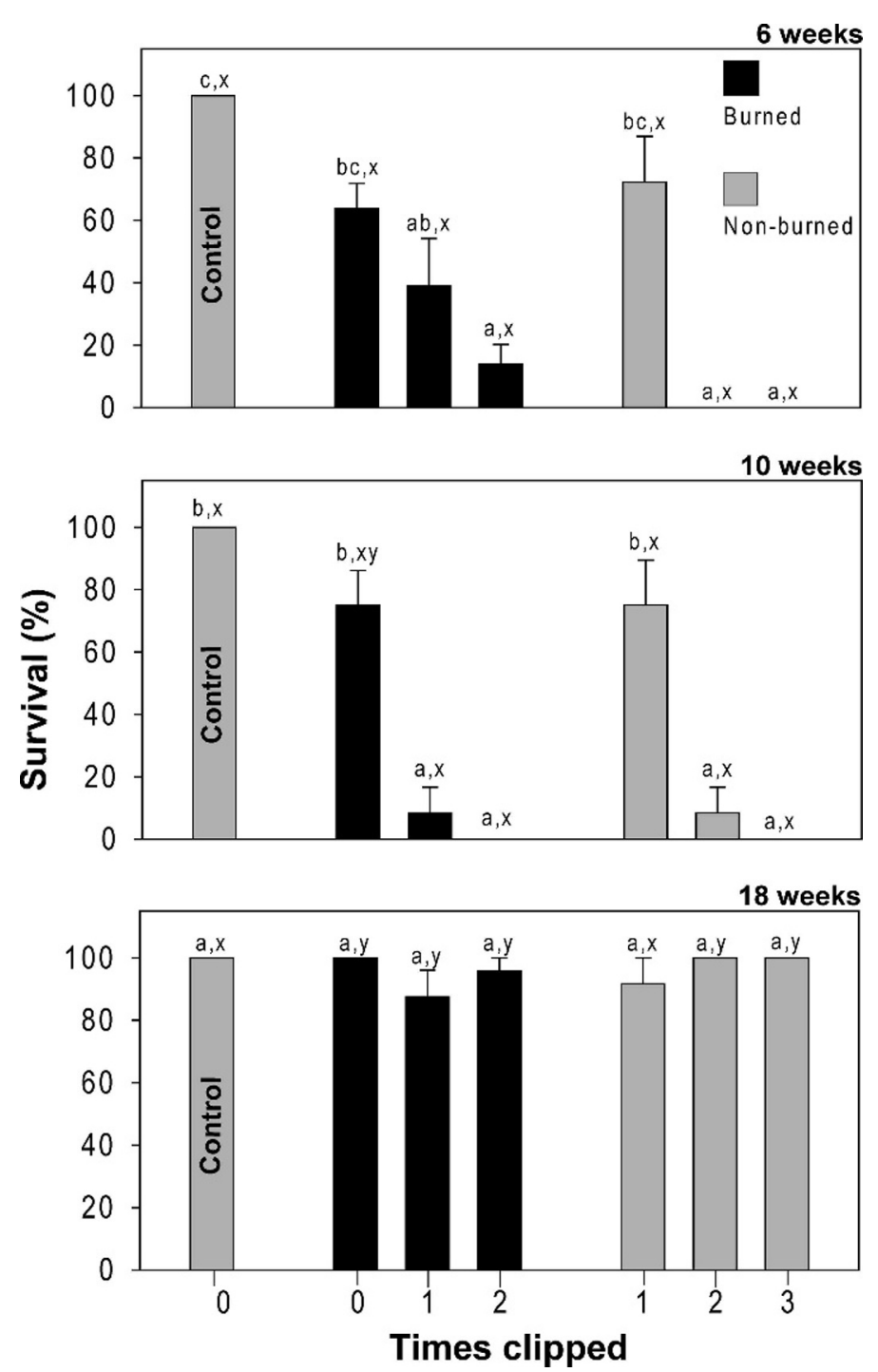

Figure 3. Survival of little bluestem plants (mean $\pm \mathrm{SE}$ ) burned or clipped at 6 wk, 10 wk, or 18 wk postgermination. Treatment bars with different letters differ at $P \leq 0.05$ with the letters $\mathrm{a}, \mathrm{b}$, and $\mathrm{c}$ identifying differences among treatments within an age group, and the letters $x$ and $y$ identifying differences among age groups within a treatment.

treatments with increased age. Survival of plants in the 18-wk postgermination treatment group was more than $90 \%$ in all treatments, and did not differ among all combinations of burning and clipping.

The interaction of burning and clipping affected the aboveground regrowth of the 18 -wk postgermination treatment group $(P \leq 0.05$; Fig. 4). Burning without clipping increased plant aboveground regrowth compared to plants that were neither burned nor clipped $(P \leq 0.05)$, whereas clipping without burning decreased aboveground regrowth $(P \leq 0.05$; Fig. 4). Plants that were burned averaged $0.3 \mathrm{~g}$ for the first clip and $0.1 \mathrm{~g}$ for the second clip, whereas clip-only plants averaged 22.9 , less than 0.01 , and $0.0 \mathrm{~g}$ for first, second, and third clips, respectively. Clipping burned plants decreased regrowth compared to burning alone $(P \leq 0.05)$, but clipping without burning consistently reduced aboveground regrowth $(P \leq 0.05)$. Moreover, clipping twice following burning did not

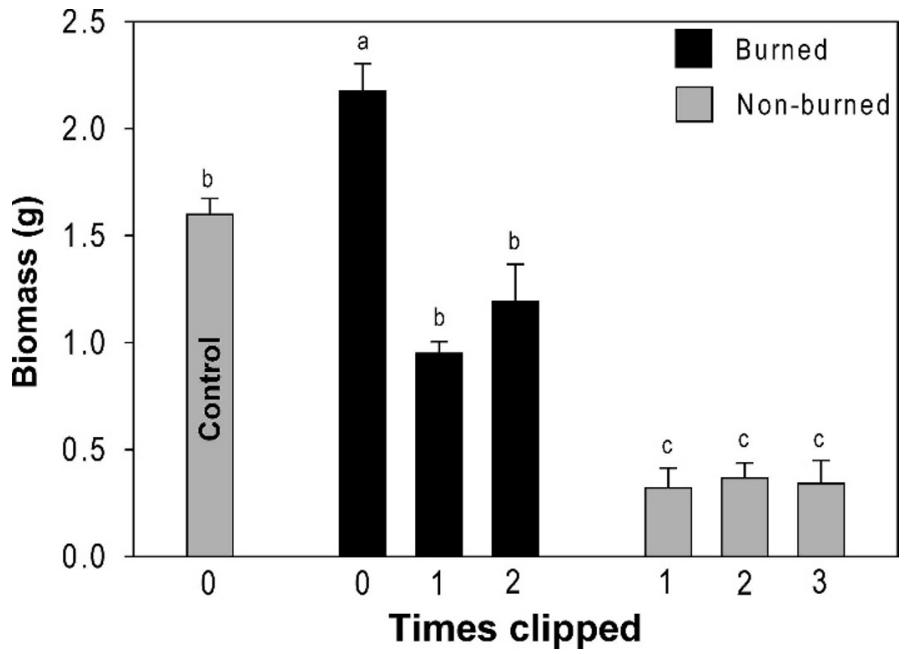

Figure 4. Aboveground biomass harvested from little bluestem plants subjected to burning and clipping beginning at 18 wk postgermination. Bars are treatment means \pm standard error $(n=3)$. Treatment bars with different letters differ at $P \leq 0.05$.

reduce aboveground biomass more than clipping once $(P>0.05)$.

Perhaps even more striking is that burning increased $(P \leq 0.05)$ rather than decreased belowground biomass in all clipping treatments compared to all other treatments that were not burned (Fig. 5). Additionally, burning followed by both one and two clipping events did not decrease belowground biomass below that of burning without clipping $(P>0.05)$. The number of clipping events on nonburned plants also did not affect belowground biomass.

\section{DISCUSSION}

Plant species composition is determined, in large part, by the evolutionary disturbance history of a grassland (Milchunas et al. 1988). However, timing of a disturbance can be just as influential as the type, severity, and frequency of disturbance (Grime 2001). We imposed dormant-season fire and growingseason fire followed by intense herbivory to a fire-adapted plant community in which $25 \%$ of the plant community composition is contributed by little bluestem, a presumed firesensitive grass species. Our study revealed that the plant community was unaffected by fire season and that the little bluestem population, strongly influenced by precipitation, was unaffected by season of fire followed by grazing. These results are supported by data from the greenhouse study in which we found that little bluestem survival was strongly dependent on plant age, and the effect of burning followed by clipping was similar to multiple clipping events. Burning increased aboveground biomass and belowground biomass of clipped and nonclipped plants, yet burning had less negative effect on little bluestem than did clipping. These results strongly suggest little bluestem is more resistant to growing-season fire than is commonly believed.

The effects of fire on plant communities are strongly influenced by factors affecting fire intensity (Twidwell et al. 2009). Growing-season fire can result in inconsistent plant 


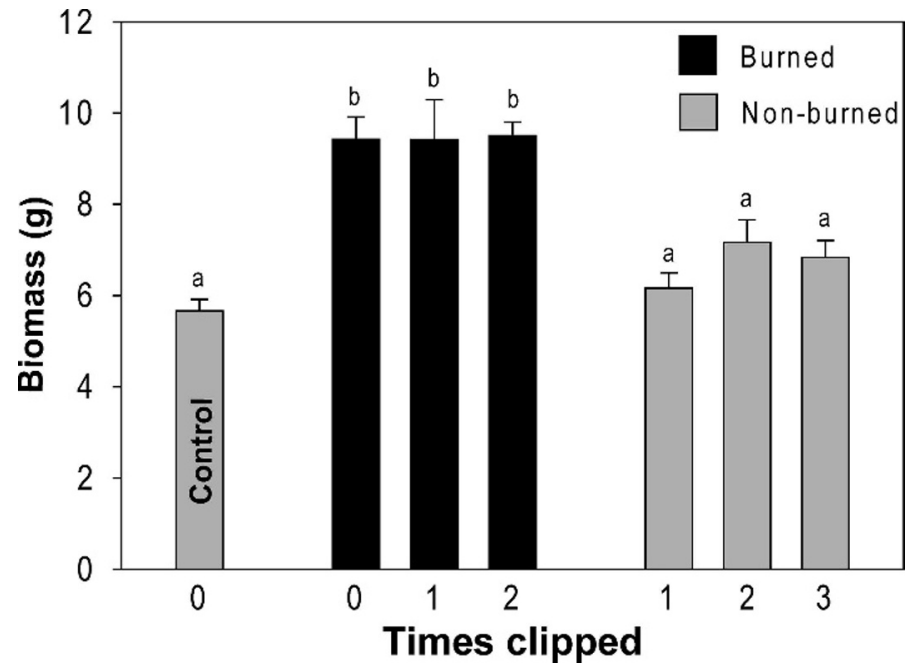

Figure 5. Belowground biomass of little bluestem plants subjected to burning and clipping at 18 wk postgermination. All values are block means \pm standard error $(n=3)$. Letters represent differences at $P \leq 0.05$.

community composition, productivity, and individual species abundance. Problematic with reporting fire effects under broad labels such growing-season or summer fire is that fire intensity can be highly variable from one fire to the next in a given season. Fuel type and fuel load, air temperature, relative humidity, and wind speed can all affect fire intensity, which can ultimately affect vegetation (Wright and Bailey 1982). Burning within a climate-controlled environment (greenhouse) produced near-uniform burns, with relatively high maximum fire temperature, yet burning had little negative influence on survival of 18 -wk-old little bluestem plants. However, it is likely that plant response would be different with increased or decreased fire intensity or followed by drought conditions.

Prefire and postfire environmental conditions influence individual plant and plant community response (Knapp 1985; Teague et al. 2008). Our results indicate that the previous year's precipitation influenced plant composition more than season of fire with a sixfold greater range in little bluestem cover among years than between dormant- and growing-season fire. Soil moisture was identified as the single most critical factor affecting vegetation recovery following fire in the southern mixed prairie (Wright 1974). Drought following fire, regardless of season, can exacerbate fire effects (Wright 1974; Fuhlendorf and Smeins 1997) and delay recovery beyond $3 \mathrm{yr}$ in some instances (Teague et al. 2008). However, with adequate precipitation, grazing following fire did not influence the plant community (Valone et al. 2002). This is consistent with the results of our greenhouse study, where burning followed by clipping did not affect seedling survival or aboveground regrowth and increased belowground biomass.

An unexpected result of burning in our study was an increase in both aboveground regrowth and belowground biomass. Increased aboveground regrowth is consistent with the concept of compensatory growth following defoliation (Hilbert et al. 1981). To compensate for the increased aboveground growth rate, plants often reallocate carbon and other essential nutrients from root reserves to aboveground photosynthetic tissue
(Detling et al. 1979; Richards 1984; Belsky 1986; Briske et al. 1996), temporarily decreasing belowground biomass. However, in contrast to traditional plant compensatory growth response, burning reversed the negative effect of clipping on aboveground regrowth, and stimulated belowground plant biomass in our greenhouse study. Resource availability influences vegetation dynamics, and small resource changes can promote or inhibit plant growth depending on timing and plant phenological state (Grime 2001). Following fire, charred plant residue and exposed soil absorb solar radiation, which increases soil temperatures and promotes soil microbial activity. This often leads to increased plant nutrient availability (Blair et al. 1998) and enables rapid vegetative and root growth that can exceed that of nonburned plants (Seastedt and Ramundo 1990; Ojima et al. 1994; Blair et al. 1998). Increased plant biomass in our greenhouse study was unlikely to be the result of postfire soil warming and enhanced microbial activity. Exposure to extreme heat might trigger a plant-growth regulator response, leading to increased herbaceous production. Prolonged exposure to high but nonlethal temperatures increased auxin-mediated cell elongation in Arabidopsis spp. (Gray et al. 1998). Soil surface temperatures during fire events are temporarily elevated above ambient air temperature, but soil insulates belowground plant structures from thermal extremes.

Smoke residuals from burned cellulose in postfire environments increases germination rate (De Lange and Boucher 1990; Brown 1993; Baldwin and Morse 1994), seedling vigor (Chiwocha et al. 2009), and rooting (Taylor and van Staden 1996). The compound 3-methyl-2H-furo[2,3-c]pyran-2-one, identified in smoke, promoted root formation and growth (Taylor and van Staden 1996), and increased plant survival nearly $30 \%$ (van Staden et al. 2006). Although our results are inconclusive and additional focused investigation is necessary to elucidate the mechanisms involved, temperature-induced hormonal growth or response to smoke-derived compounds might provide insight to plant survival and increased aboveground biomass and belowground biomass following fire even when followed by grazing.

Frequently, it is suggested that grazing on native rangelands needs to be deferred after fire to allow grasses to recover and prevent species decline and land degradation (Scifres and Hamilton 1993; Ansley and Taylor 2004; Teague et al. 2010). As an alternative to resting land after fire, several studies indicate that immediate use following fire replicates historic disturbance regimes and is beneficial to the ecosystem (Fuhlendorf and Engle 2001, 2004; Fuhlendorf et al. 2009). Burning followed by clipping can reduce the survival of young plants (6 wk and $10 \mathrm{wk}$ ) compared to clipping alone; therefore annual burning and grazing consecutive years could have negative consequences, but grass ramet recruitment by seed is less than 1\% in the Great Plains (Benson and Hartnett 2006); therefore long-term shifts in species composition and increased plant mortality are not likely.

\section{MANAGEMENT IMPLICATIONS}

In grassland landscapes fire promotes ecosystem productivity by increasing light availability (Hulbert 1969; Knapp and 
Seastedt 1986; Knapp et al. 1998) and stability by limiting woody encroachment (Fuhlendorf and Smeins 1997; MacDougall 2005; Taylor 2005). The use of growing-season fire in grassland ecosystems enables land managers to extend the traditional dormant-fire season and actively burn throughout the year with minor or no negative impact on grass survival, which promotes stable plant community composition. Further, growing-season burns enhance both aboveground and belowground productivity, which may lead to greater soil organic matter, which strongly influences carbon sequestration (Gill et al. 1999; Jobbagy and Jackson 1999).

Management-intensive grazing systems (i.e., rotational grazing) are implemented to manipulate the timing, intensity, and frequency of grazing (Briske et al. 2008), often with a single defoliation event each season, the target for individual grass tillers to reduce potential grazing damage. Fire is seldom considered as part of these grazing systems, presumably to limit damage to herbaceous plants. However, when comparing the effects of a single clipping event to a burn followed by a single clipping event on mature plants (18 wk), the results do not support the removal of fire from little bluestem grasslands. Our results indicate that mature little bluestem is well adapted to growing-season disturbance whether from grazing or fire, and will not decline under the interacting influence of fire and herbivory during the growing season. Moreover, little bluestem plants appear to benefit from growing-season burning with increased aboveground regrowth and belowground biomass, which suggests deferment from grazing after burning or the removal of fire from the landscape is unjustified as part of an overall land management strategy.

\section{ACKNOWLEDGMENTS}

We thank K. Hickman, J. Weir, D. Twidwell, and numerous technicians for assistance with various aspects of this study.

\section{LITERATURE CITED}

Allred, B. W. 2008. Plants, grazing and fire in tallgrass prairie [M.S. thesis]. Stillwater, OK, USA: Oklahoma State University. 74 p.

Anderson, K. L., E. F. Smith, and C. E. Owensby. 1970. Burning bluestem range. Journal of Range Management 23:81-92.

AndeRson, M. J. 2001. A new method for nonparametric multivariate analysis of variance. Austral Ecology 26:32-46.

Anderson, R. H., S. D. Fuhlendorf, and D. M. Engle. 2006. Soil N availability in tallgrass prairie under the fire-grazing interaction. Rangeland Ecology \& Management 59:625-631.

Ansley, R. J., M. J. Castellano, and W. E. Pinchak. 2006. Sideoats grama growth responses to seasonal fires and clipping. Rangeland Ecology \& Management $59: 258-266$

Ansley, R. J., W. E. Pinchak, and D. L. Jones. 2008. Mesquite, tobosagrass, and common broomweed responses to fire season and intensity. Rangeland Ecology \& Management 61:588-597.

Ansley, R. J., And C. A. Taylor. 2004. The future of fire as a tool for managing brush. In: W. T. Hamilton, A. McGinty, D. N. Ueckert, C. W. Hanselka, and M. R. Lee [EDS.]. Brush management: past, present and future. College Station, TX, USA: Texas A\&M University Press. p. 200-212.

Archibald, S., W. J. Bond, W. D. Stock, and D. H. K. Fairbanks. 2005. Shaping the landscape: fire-grazer interactions in an African savanna. Ecological Applications 15:96-109.
Augustine, D. J., and S. J. McNaughton. 1998. Ungulate effects on the functional species composition of plant communities: herbivore selectivity and plant tolerance. Journal of Wildlife Management 62:1165-1183.

AxelRod, D. 0. 1985. Rise of the grassland biome, central North America. Botanical Review 51:163-202.

Baldwin, I. T., and L. Morse. 1994. Up in smoke. II. Germination of Nicotiana attenuata in response to smoke-derived cues and nutrients in burned and unburned soils. Journal of Chemical Ecology 20:2373-2391.

Belsky, A. J. 1986. Does herbivory benefit plants-a review of the evidence. American Naturalist 127:870-892.

Benson, E. J., and D. C. Hartnett. 2006. The role of seed and vegetative reproduction in plant recruitment and demography in tallgrass prairie. Plant Ecology 187:163-177.

Bidwell, T. G., D. M. Engle, and P. L. Claypool. 1990. Effects of spring headfires and backfires on tallgrass prairie. Journal of Range Management 43:209212.

Biondini, M. E., B. D. Patton, and P. E. Nyren. 1998. Grazing intensity and ecosystem processes in a northern mixed-grass prairie, USA. Ecological Applications 8:469-479.

Biondini, M. E., A. A. Steuter, and R. G. Hamilton. 1999. Bison use of fire-managed remnant prairies. Journal of Range Management 52:454-461.

BLAIR, J. M. 1997. Fire, N availability, and plant response in grasslands: a test of the transient maxima hypothesis. Ecology 78:2359-2368.

Blair, J. M., T. R. Seastedt, C. W. Rice, and R. A. Ramundo. 1998. Terrestrial nutrient cycling in tallgrass prairie. In: A. K. Knapp, J. M. Briggs, D. C. Hartnett, and S. L. Collins [EDS.]. Grassland dynamics: Iong-term ecological research in tallgrass prairie. New York, NY, USA: Oxford University Press. p. 222243.

BRAGG, T. B. 1982. Seasonal variations in fuel and fuel consumption by fires in a bluestem prairie. Ecology 63:7-11.

Bragg, T. B., and L. C. Hulbert. 1976. Woody plant invasion of unburned Kansas bluestem prairie. Journal of Range Management 29:19-23.

BRAnSEN, F. A. 1953. Two new factors affecting resistance of grasses to grazing. Journal of Range Management 6:165-171.

Briske, D. D., T. W. Boutton, and Z. Wang. 1996. Contribution of flexible allocation priorities to herbivory tolerance in $\mathrm{C}-4$ perennial grasses: an evaluation with C-13 labeling. Oecologia 105:151-159.

Briske, D. D., J. D. Derner, J. R. Brown, S. D. Fuhlendorf, W. R. Teague, K. M. Havstad, R. L. Gillen, A. J. Ash, and W. D. Willms. 2008. Rotational grazing on rangelands: reconciliation of perception and experimental evidence. Rangeland Ecology \& Management 61:3-17.

BRITTON, C. 2005. Observations on fire and wildlife. In: C. G. Brown and D. Rollins [EDS.]. Fire as a tool for managing wildlife habitat in Texas. San Angelo, TX, USA: Texas Cooperative Extension Service. p. 42-49.

Brown, J. R., AND S. ARCHER. 1989. Woody plant invasion of grasslands: establishment of honey mesquite (Prosopis glandulosa var. glandulosa) on sites differing in herbaceous biomass and grazing history. Oecologia 80:19-26.

Brown, N. A. C. 1993. Promotion of germination of fynbos seeds by plant derived smoke. New Phytologist 123:575-583.

ButLeR, J. L., AND D. D. BRISKE. 1988. Population structure and tiller demography of the bunchgrass Schizachyrium scoparium in response to herbivory. Oikos $51: 306-312$

Chimocha, S. D. S., K. W. Dixon, G. R. Flematti, E. L. Ghisalberti, D. J. Merritt, D. C. Nelson, J. M. Riseborogh, S. M. Smith, and J. C. Stevens. 2009. Karrikins: a new family of plant growth regulators in smoke. Plant Science 177:252-256.

Collins, S. L., A. K. Knapp, J. M. Briggs, J. M. Blair, and E. M. Steinaur. 1998. Modulation of diversity by grazing and mowing in native tallgrass prairie. Science 5364:745-747.

De Lange, J. H., And C. Boucher. 1990. Autecological studies on Audouinia capitata (Bruniaceae). I. Plant-derived smoke as a seed germination cue. South African Journal of Botany 56:700-703.

DerneR, J. D., AND D. D. Briske. 1999. Does a tradeoff exist between morphological and physiological root plasticity? A comparison of grass growth forms. Acta Oecologica 20:519-526. 
Detling, J. K., M. I. Dyer, and D. T. Winn. 1979. Net photosynthesis, root respiration, and regrowth of Bouteloua gracilis following simulated grazing. Oecologia 41:127-134.

Engle, D. M., and T. G. Bidwell. 2001. Viewpoint: the response of Central North American prairies to seasonal fire. Journal of Range Management 54:2-10.

Engle, D. M., T. G. Bidwell, J. F. Stritzke, and D. Roluins. 1990. Atrazine and burning in tallgrass prairie infested with prairie three-awn. Journal of Range Management 43:424-427.

Engle, D. M., R. L. Mitchell, and R. L. Stevens. 1998. Growing-season fire effects on forage production in mid-successional tallgrass prairie. Journal of Range Management 51:115-121.

Engle, D. M., J. F. Stritzke, T. G. Bidwell, and P. L. Claypool. 1993. Late-summer fire and follow-up herbicide treatments in tallgrass prairie. Journal of Range Management 46:542-547.

Ewing, A. L., And D. M. Engle. 1988. Effects of late summer fire on tallgrass prairie microclimate and community composition. American Midland Naturalist 120:212-223.

Ford, P. L., AND G. V. Johnson. 2006. Effects of dormant- vs growing season fire in shortgrass steppe: biological soil crust and perennial grass responses. Journal of Arid Environments 6:1-14.

Frank, D. A., and S. J. McNaughton. 1993. Evidence for the promotion of aboveground grassland production by native large herbivores in YellowstoneNational-Park. Oecologia 6:157-161.

Fuhlendorf, S. D., AND D. M. Engle. 2001. Restoring heterogeneity on rangelands: ecosystem management based on evolutionary grazing patterns. Bioscience 51:625-632.

Fuhlendorf, S. D., And D. M. Engle. 2004. Application of the fire-grazing interaction to restore a shifting mosaic on tallgrass prairie. Journal of Applied Ecology 41:604-614.

Funlendorf, S. D., D. M. Engle, J. Kerby, and R. G. Hamilton. 2009. Pyric-herbivory: rewilding landscapes through re-coupling fire and grazing. Conservation Biology 23:588-598.

Funlendorf, S. D., And F. E. Smeins. 1997. Long-term vegetation dynamics mediated by herbivores, weather and fire in a Juniperus-Quercus savanna. Journal of Vegetation Science 8:819-828.

Gill, R., I. C. Burke, D. G. Milchunas, and W. K. Lauenroth. 1999. Relationship between root biomass and soil organic matter pools in the shortgrass steppe of eastern Colorado. Ecosystems 2:226-236.

Gray, W. M., A. Ostin, G. Sandberg, C. P. Romano, and M. Estelle. 1998. High temperature promotes auxin-mediated hypocotyls elongation in Arabidopsis. Proceedings of the National Academy of Sciences of the United States of America 12:7197-7202.

GrIme, J. P. 2001. Plant strategies, vegetation processes, and ecosystem properties. 2nd ed. New York, NY, USA: John Wiley and Sons. 416 p.

HIGGINS, K. F. 1986. Interpretation and compendium of historical fire accounts in the northern Great Plains. Washington, DC, USA: US Department of the Interior, Fish and Wildlife Service. Resource Publication 161. 39 p.

Hilbert, D. W., D. M. Swift, J. K. Detling, and M. I. Dyer. 1981. Relative growth rates and the grazing optimization hypothesis. Oecologia 51:14-18.

Howe, H. F. 1994. Response of early- and late-flowering plants to fire season in experimental prairies. Ecological Applications 4:121-133.

Hulbert, L. C. 1969. Fire and litter effects in undisturbed bluestem prairie in Kansas. Ecology 50:874-877.

Jobbagy, E. G., and R. B. Jackson. 2000. The vertical distribution of soil organic carbon and its relation to climate and vegetation. Ecological Applications 10:423-436.

Johnson, L. C., and J. R. Matchett. 2001. Fire and grazing regulate belowground processes in tallgrass prairie. Ecology 82:3377-3389.

KnapP, A. K. 1985. Effect of fire and drought on the ecophysiology of Andropogon gerardii and Panicum virgatum in a tallgrass prairie. Ecology 66:1309-1320.

Knapp, A. K., J. M. Blair, J. M. Briggs, S. L. Collins, D. C. Hartnett, L. C. Johnson, and E. G. Towne. 1999. The keystone role of bison in North American tallgrass prairie. Bioscience 49:39-50.

Knapp, A. K., J. M. Briggs, J. M. Blair, And C. L. TuRner. 1998. Patterns and controls of aboveground net primary production in tallgrass prairie. In: A. K. Knapp,
J. M. Briggs, D. C. Hartnett, and S. C. Collins [EDS.]. Grassland dynamics: longterm ecological research in tallgrass prairie. New York, NY, USA: Oxford University Press. p. 193-221.

Knapp, A. K., And T. R. Seastedt. 1986. Detritus accumulation limits productivity of tallgrass prairie. Bioscience 36:662-668.

Limb, R. F., D. M. Engle, T. G. Bidwell, D. P. Althoff, A. B. Anderson, P. S. Gipson, AND H. R. Howard. 2010a. Restoring biopedturbation in grasslands with anthropogenic focal disturbance. Plant Ecology 210:331-342.

Limb, R. F., D. M. Engle, S. D. Fuhlendorf, D. P. Althoff, and P. S. Gipson. 2010b. Altered herbivore distribution associated with focal disturbance. Rangeland Ecology \& Management 63:253-257.

MacDougall, A. S. 2005. Responses of diversity and invisibility to burning in a northern oak savanna. Ecology 86:3354-3363.

McCune, B., And J. B. Grace. 2002. Analysis of ecological communities. Gleneden Beach, OR, USA: MjM Software Design. p. 188-197.

McNaughton, S. J. 1984. Grazing lawns-animals in herds, plant form, and coevolution. American Naturalist 124:863-886.

Mılchunas, D. G., O. E. Sala, and W. K. Lauenroth. 1988. A generalized model of the effect of grazing by large herbivores on grassland community structure. American Naturalist 132:87-106.

OJima, D. S., D. S. Schimel, W. J. Parton, And C. E. Owensby. 1994. Long- and shortterm effects of fire on nitrogen cycling in tallgrass prairie. Biogeochemistry 24:67-84.

Palo, R. T., and C. T. Robbins. 1991. Plant defenses against mammalian herbivory. Boca Raton, FL, USA: CRC Press. 192 p.

Peco, B., A. M. Sanchez, and F. M. Azcarate. 2006. Abandonment in grazing systems: consequences for vegetation and soil. Agriculture Ecosystems and Environment 113:284-294.

RichardS, J. H. 1984. Root growth response to defoliation in two Agropyron bunchgrasses: field observations with an improved root periscope. Oecologia 64:21-25.

Rosenthal, J. P., And P. M. Kotanen. 1994. Terrestrial plant tolerance to herbivory. Trends in Ecology and Evolution 9:145-148.

Scifres, C. J., and W. T. Hamilton. 1993. Prescribed burning for brushland management: the south Texas example. College Station, TX, USA: Texas A\&M University Press. 246 p.

Seastedt, T. R., and R. A. Ramundo. 1990. The influence of fire on belowground processes of tallgrass prairie. In: S. L. Collins and L. L. Wallace [EDS.]. Fire in North American tallgrass prairies. Norman, OK, USA: University of Oklahoma Press. p. 99-117.

SousA, W. P. 1984. The role of disturbance in natural communities. Annual Review of Ecology and Systematics 15:353-392.

SPSS. 2005. SPSS guide to data analysis, release 14.0. Old Tappan, NJ, USA: SPSS. $652 \mathrm{p}$.

Steel, R. D., J. H. Torrie, and D. A. Dickey. 1997. Principles and procedures of statistics. A biometrical approach. 3rd ed. Boston, MA, USA: McGraw-Hill. p. 557-558.

TAYLOR, C. A., JR. 2005. Ecological consequences of using prescribed fire and herbivory to manage Juniperus encroachment. In: 0. W. Van Auken [ED.]. Western North American Juniperus communities: a dynamic vegetation. New York, NY, USA: Springer. p. 239-252.

TAYloR, J. L. S., And J. van Staden. 1996. Root initiation in Vigna radiata (L.) Wilczek hypocotyl cutting is stimulated by smoke-derived extracts. Plant Growth Regulation 18:165-168.

Teague, W. R., S. L. Dowhower, R. J. Ansley, W. E. Pinchak, and J. A. Waggoner. 2010. Integrated grazing and prescribed fire restoration strategies in a mesquite savanna: I. Vegetation responses. Rangeland Ecology \& Management 63:275-285.

Teague, W. R., S. E. Duke, J. A. Waggoner, S. L. Dowhower, and S. A. GerRard. 2008. Rangeland vegetation and soil response to summer patch fires under continuous grazing. Arid Land Research and Management 22: 228-241.

Towne, E. G., D. C. Hartnett, and R. C. Cochran. 2005. Vegetation trends in tallgrass prairie from bison and cattle grazing. Ecological Applications 15: 1550-1559. 
Towne, G., AND C. OWEnsBy. 1984. Long-term effects of annual burning at different dates in ungrazed Kansas tallgrass prairie. Journal of Range Management 37:392-397.

Twidwell, D. S., D. Fuhlendorf, D. M. Engle, and C. A. Taylor, Jr. 2009. Surface fuel sampling strategies: linking fuel measurements and fire effects. Rangeland Ecology \& Management 62:223-229.

Valone, T. J., S. E. Nordell, and S. K. M. Ernest. 2002. Effects of fire and grazing on an arid grassland ecosystem. The Southwestern Naturalist 47:557-565.

van Staden, J., S. G. Sparg, M. G. Kulharni, and M. E. Light. 2006. Postgermination effects of the smoke-derived compound 3-methyl-2H-furo[2,3-c] pyran-2-one, and its potential as a preconditioning agent. Field Crops Research 98:98-105.
VogL, R. J. 1974. Effects of fire on grasslands. In: T. T. Kozlowski and C. E. Ahlgren [EDS.]. Fire and ecosystems: a series of monographs, texts, and treatises. New York, NY, USA: Academic Press. p. 139-194.

WEST, N. E. 1993. Biodiversity of rangelands. Journal of Range Management 46:2-13.

WhISENANT, S. G. 1999. Repairing damaged wildlands: a process-oriented, landscape-scale approach. Cambridge, United Kingdom: Cambridge University Press. $312 \mathrm{p}$

WRIGHT, H. A. 1974. Effect of fire on southern mixed prairie grasses. Journal of Range Management 27:417-419.

Wright, H. A., and A. W. Balley. 1982. Fire ecology. New York, NY, USA: John Wiley and Sons. $501 \mathrm{p}$. 